\title{
Smart Online Courses Using Computational Intelligence
}

\author{
https://doi.org/10.3991/ijim.v14i12.15601 \\ Irawan Dwi Wahyono ( $\left.{ }^{\varpi}\right)$, Djoko Saryono, Khoirudin Asfani, \\ Muhammad Ashar, Sunarti \\ Universitas Negeri Malang, Malang, Indonesia \\ irawan.dwi.fteum.ac.id
}

\begin{abstract}
Computer network security has become an important issue in recent decades, the government and several international organizations have invested in professional education and training for computer network security. In addition, with the increasing incidence of computer network security crimes, the government and several organizations have taken precautions by providing training to students about computer network security. Some parties develop learning models that are suitable for students and find appropriate learning methods to produce professionals in the field of computer network security that is more effective. The purpose of this study is to design a framework-based Learning system in the form of an Adaptive Online Open Course in Computer System Security Subjects for Information Technology (IT) students. The benefits of this framework are to enhance students' skills and abilities in industrialbased computer network security, startup companies and the ability to complete CTF competitions in IT network security. The framework designed is Adaptive in which students learn according to the interests and topics of Computer Network Security. Interest-based on students in completing the pretest per topic. Testing in this study is testing the impact and improvement of students' learning abilities and skills on Computer Security and Security System Competence testing in a small group consisting of 20 students by seeing the success of completing 3 CTF Topics with each topic totaling 100 computer network security problems in the CTF competition, the average validation result was $83.01 \%$ and the CTF exam passing rate was $93 \%$.
\end{abstract}

Keywords-Online course, smart, network security

\section{Introduction}

Computer network security has become an important issue in recent decades, the government and several international organizations have invested in professional education and training for computer system security. In addition, with the increasing incidence of computer network security crime, the government and several organizations have prevented it by learning from students about computer network security. Some parties develop learning models that are appropriate for students and find appropriate learning methods to produce professionals in the field of computer network 
security that are more effective[1-5]. Some international organizations concerned with computer network security hold computer network security competitions such as Capture the Flag [6], providing valuable experience for young people, especially students in learning and implementing skills and competencies about computer network security like the real world [6]. Incorporating computer system security competition in online learning systems, adding value in motivating students and playing a direct role and contributing to computer network security [4-6].

In general, there are many challenges and problems faced in organizing learning in computer network security courses, especially in the selection of models, methods and strategies suitable for online learning participants. In other parts, students must have skills and competencies in accordance with the industrial world such as honing abilities in computer network security competition. One way is to take part in online judge competitions such as CTF. Many students who fail cannot even solve a single problem in CTF judge online competition [6]. To combine learning and competition online judge learning for a computer network security course that is interrelated between the material and capabilities desired by the industry and the world of IT network security [6-7].

The main competencies of computer network security courses at the university level may be different from each type of study program, but the basic competencies can be assured of the same. Students may have different interests in the topic of computer network security. Study programs that offer computer network security courses in the curriculum include S1 in Informatics Engineering Education (PTI) and S1 in Informatics Engineering (IT), the 2014 curriculum and computer network security competitions held by KKNI based on the computer network security industry. The open online course development model must also be adaptive to the topics requested by students to specialize in certain areas of computer network [7-11]. Likewise, competency testing must be adaptive according to the interests and choices of students' chosen topics.

In this research, the online course will be developed in the form of an adaptive Open Online Course for the Computer System Security Course. It is hoped that this research can make it easier for students to explore computer system security courses and participate in international CTF competitions

\section{$2 \quad$ Method}

This study uses methods and models to develop materials and test adaptive frameworks. The model of making an open online course uses the Dick and Carey model [13] and is carried out by following ten procedural steps that refer to the recommendations of Borg and Gall [14-16]starting from collecting the data needed for assessment to produce the product being tested and disseminated to users. In practice, there are ten steps or steps that must be performed on the R\&D method [17-21], including:

1. The research stage of information gathering (research and information gathering);

2. The planning stage (planning); 
3. The stage of building a product pre-plan (developing an introduction to the product);

4. The stage of conducting initial field testing;

5. Product revision stage (main product revision);

6. Stage of product testing in the field (main field testing);

7. Operational product revision stage;

8. Stages of conducting operational tests in the field (operational field trials);

9. The final product revision stage; and

10. The stages of dissemination and implementation.

The procedure for developing this research material is shown in Figure 1.

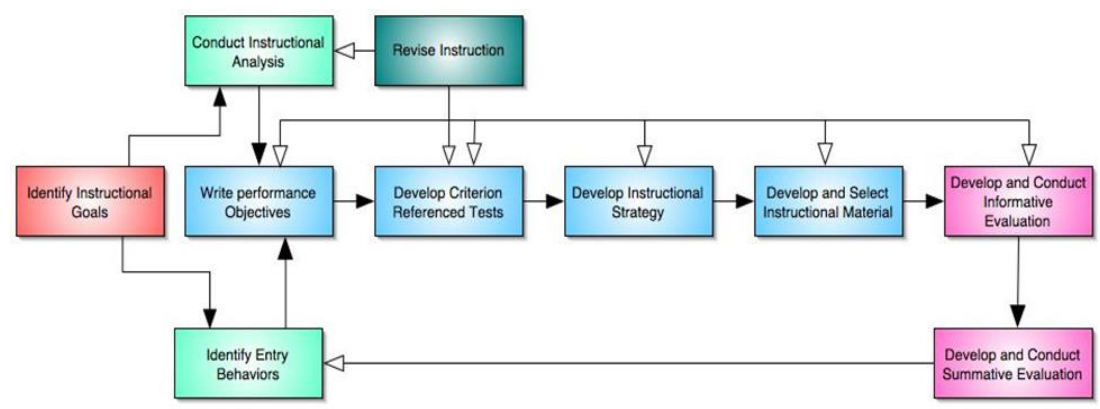

Fig. 1. Learning material model

The design, implementation and testing methods for the adaptive framework use the R\&D method as shown in Figure 2.

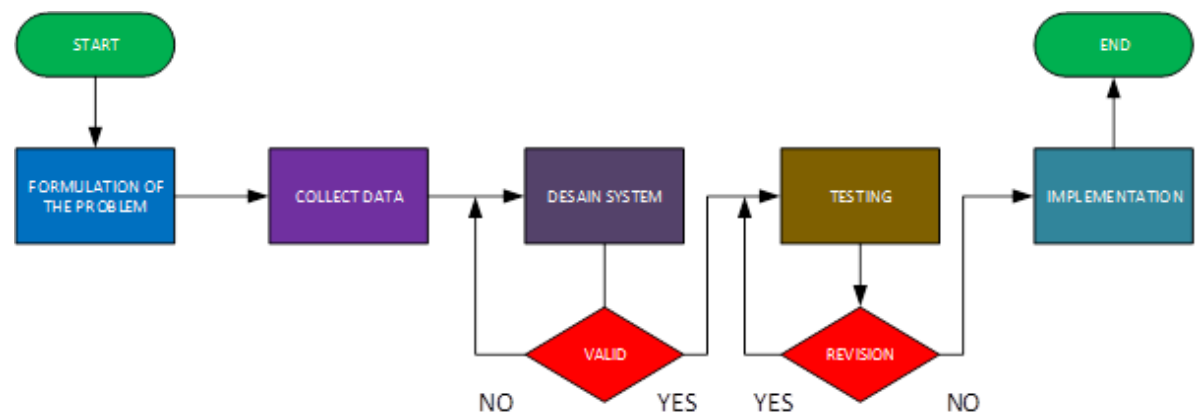

Fig. 2. R\&D methods for implementing frameworks

\subsection{Formulating problems in the CTF competition and computer network security course material}

In this first step, the noted all the models of computer network security problems in the CTF competition. The difficulty of the problem on the CTF web as shown in Figure 3 . 


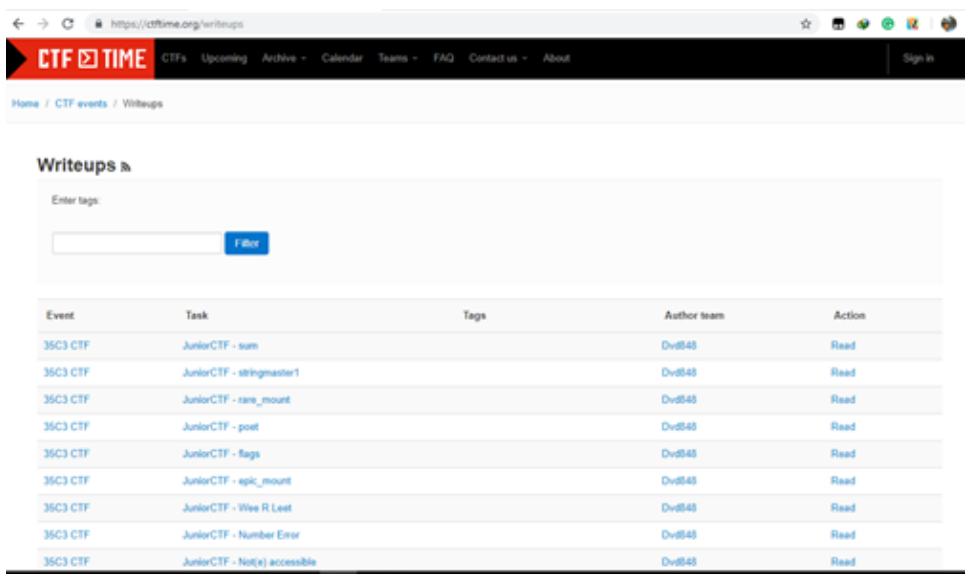

Fig. 3. The CTF web part of the write-up has difficulty

\subsection{Data CTF}

The second step in this research is to collect data on questions and solutions in the CTF competition and then discuss them based on the many solutions that have been solved by the competition participants. An example of a solution to the CTF problem as shown in Figure 4.

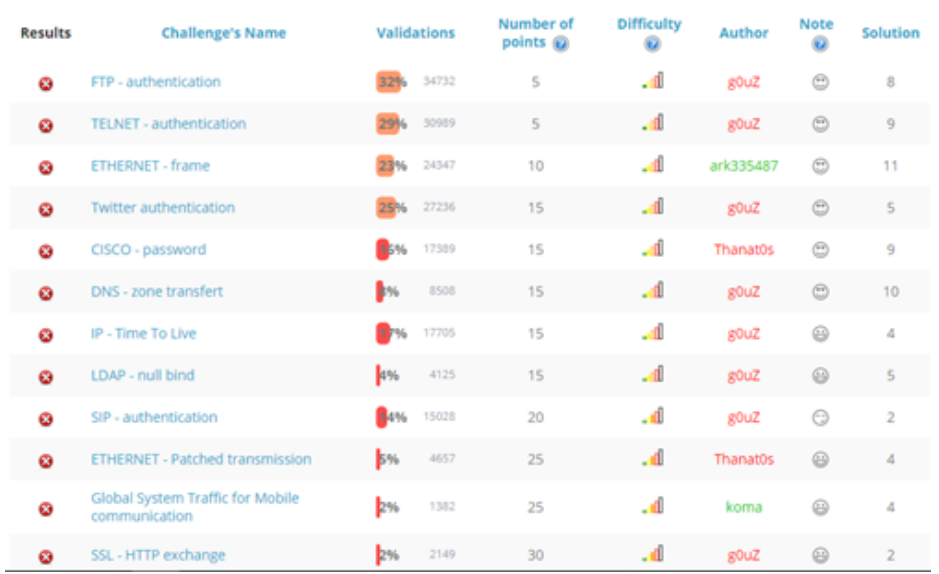

Fig. 4. CTF problems solved in the web root.me

\subsection{Framework smart open online courses}

The next step in this research is to create a framework for open online courses to solve difficulties in the form of adaptive online courses based on topics to solve questions and interests of CTF users. The design of this system is shown in Figure 5. The course manager is the admin who manages the framework. The instructor is the teach- 
er to guide the user in helping to solve CTF questions. Students are users who only see existing solutions but do not participate in the course. Users are users who take the course.

The working principle of this framework is as follows:

1. The user enters, then performs a pre-test to determine the topic to be taken

2. This Adaptive Module evaluates the results of the pre-test to suggest taking the topic of the course.

3. The pre-test assessment is conducted by the instructor then suggests taking certain topics according to the pre-test results.

4. Users attend courses and practice CTF questions

5. Users take the exam on the CTF.org website which is linked to this system, so the system evaluates results based on CTF.org then this system provides solutions to questions that do not pass.

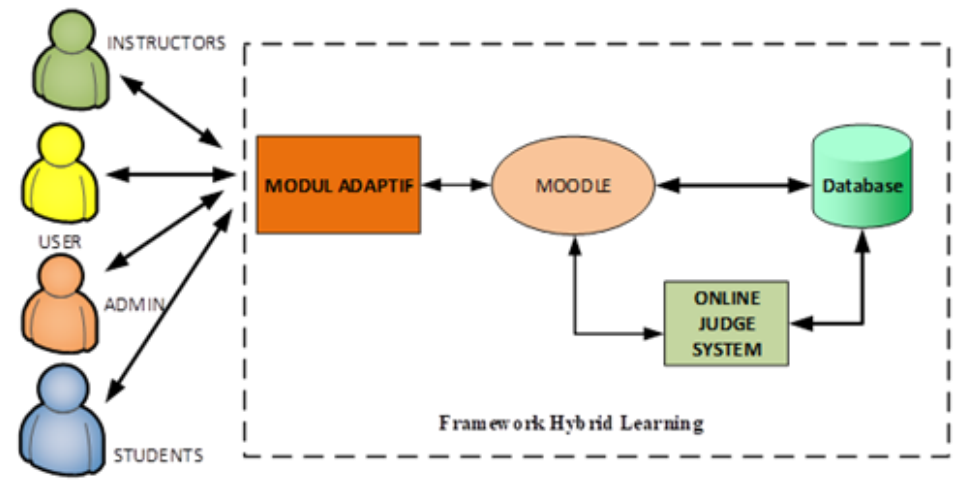

Fig. 5. Framework design

For hardware specifications required on this system are shown in Table 1. Table 2 for the software specifications used on this system.

Table 1. Hardware spesifications

\begin{tabular}{|l|c|}
\hline \multicolumn{1}{|c|}{ Specifications } & Amount \\
\hline CPU & 2 \\
\hline RAM & $2 \mathrm{~GB}$ \\
\hline Swap & $2 \mathrm{~GB}$ \\
\hline Storage & $40 \mathrm{~GB}$ \\
\hline Public IP & 1 \\
\hline
\end{tabular}


Paper-Smart Online Courses Using Computational Intelligence

Table 2. Software specifications

\begin{tabular}{|l|c|}
\hline \multicolumn{1}{|c|}{ Specifications } & Description \\
\hline Web programming & PHP 7 \\
\hline Database & SQL server \\
\hline Web framework & Codelgniter \\
\hline Web template & Bootstrap \\
\hline Model Contest & $\begin{array}{c}\text { Moe Contest Environment. Licensed under MIT } \\
\text { License }\end{array}$ \\
\hline
\end{tabular}

\section{$3 \quad$ Result and Discussion}

The implementation of this research is in a web-based and mobile-based form as shown in Figure 6. This system contains topics that have been classified based on the CTF competition as shown in Figure 6.

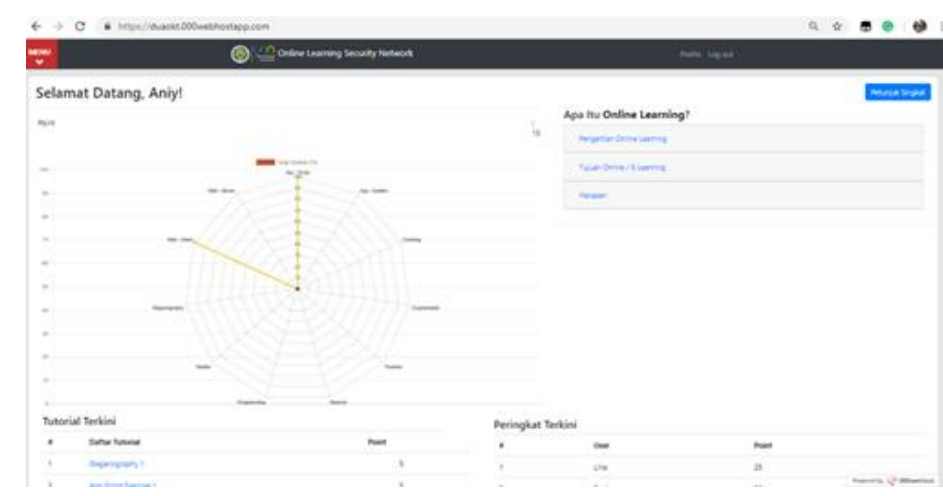

Fig. 6. Front view of open framework based online course

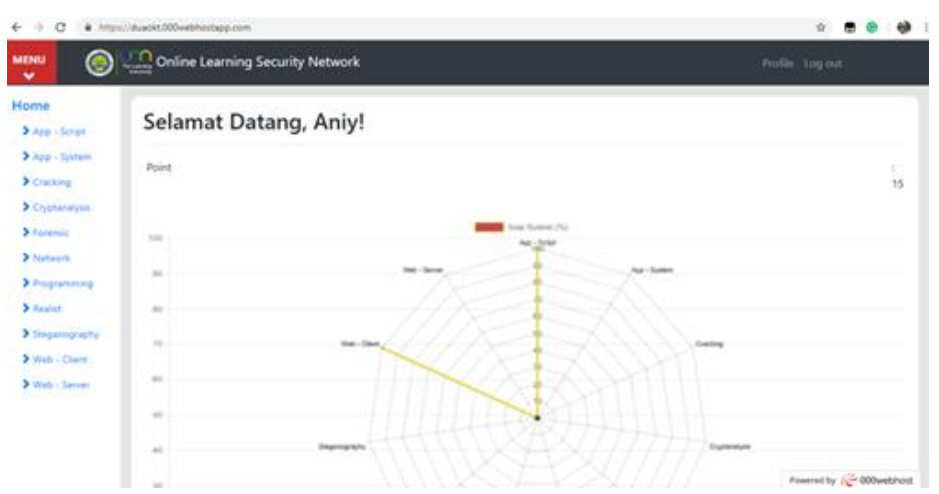

Fig. 7. Display topics that are classified according to CTF competitions 


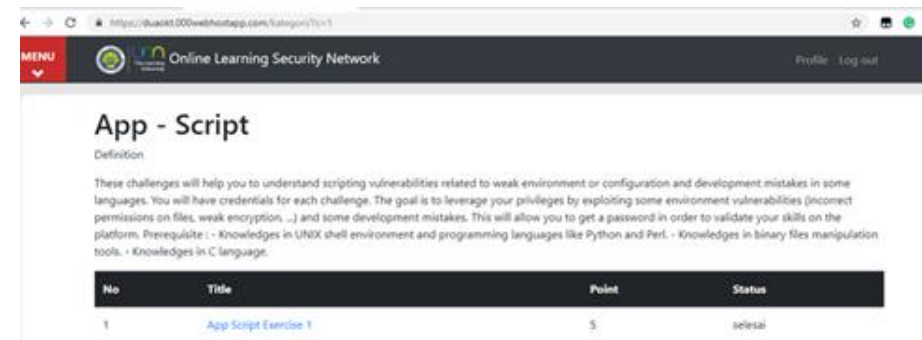

Fig. 8. The user interface has solved CTF questions on the CTF.org website

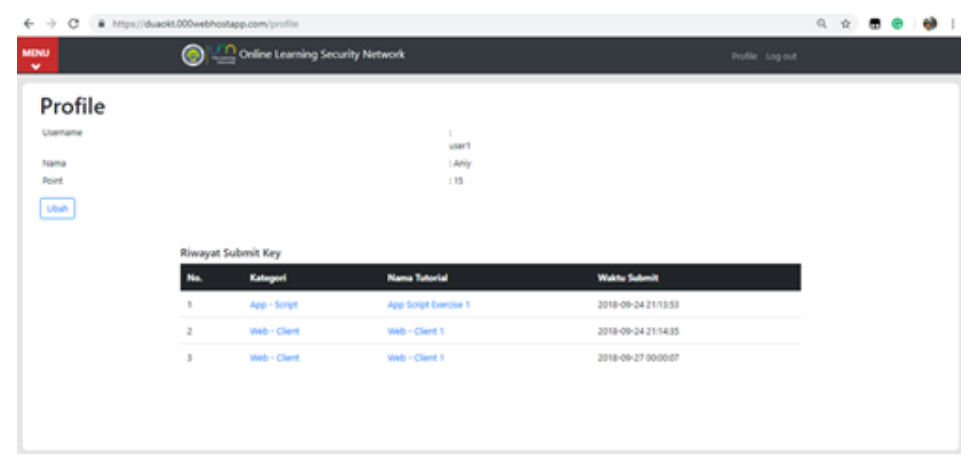

Fig. 9. Display 3 Topics that have been resolved by the user

Whereas users have completed questions based on suggested topics and then access CTF.org in the system to solve questions based on topics as shown in Figure 8. After completing all the suggested topics from 3 topics, users can see the number of results of completing CTF questions as indicated in Figure 9. In Figure 10, a graphical display in which the user has solved several CTF questions.

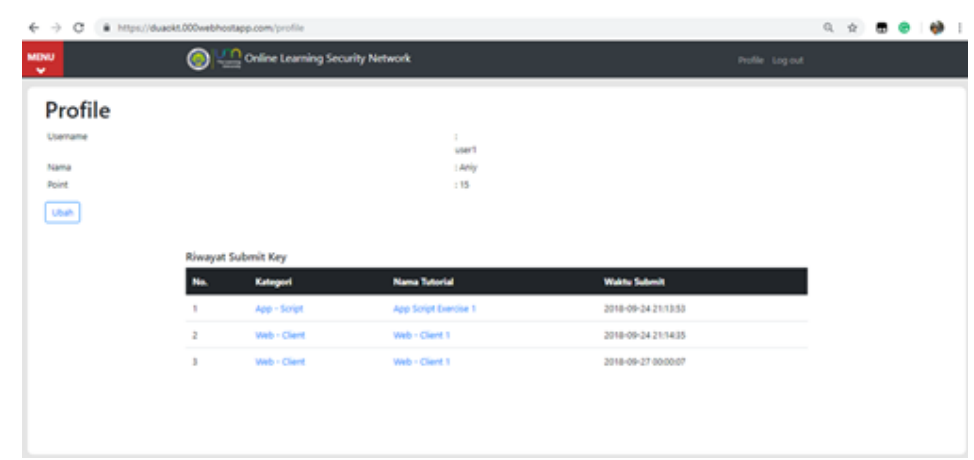

Fig. 10. Display user hassle the number of courses is taken and CTF questions that have been completed 
Table 3. Topic 1 Testing Results on users

\begin{tabular}{|c|c|c|c|}
\hline No & User & Test Result & Status \\
\hline 1 & user001 & 85 & Pass \\
\hline 2 & user002 & 85 & Pass \\
\hline 3 & user003 & 95 & Pass \\
\hline 4 & user004 & 85 & Pass \\
\hline 5 & user005 & 85 & Pass \\
\hline 6 & user006 & 85 & Pass \\
\hline 7 & user007 & 70 & Pass \\
\hline 8 & user008 & 85 & Pass \\
\hline 9 & user009 & 85 & Pass \\
\hline 10 & user010 & 85 & Pass \\
\hline 11 & user011 & 85 & Pass \\
\hline 12 & user012 & 30 & No Pass \\
\hline 13 & user013 & 85 & Pass \\
\hline 14 & user014 & 87 & Pass \\
\hline 15 & user015 & 85 & Pass \\
\hline 16 & user016 & 88 & Pass \\
\hline 17 & user017 & 85 & Pass \\
\hline 18 & user018 & 75 & Pass \\
\hline 19 & user019 & 85 & Pass \\
\hline 20 & user020 & 85 & Pass \\
\hline
\end{tabular}

Table 4. Topic 2 Testing Results on users

\begin{tabular}{|l|l|c|l|}
\hline No & User & Test Result & Status \\
\hline 1 & user001 & 88 & Pass \\
\hline 2 & user002 & 90 & Pass \\
\hline 3 & user003 & 90 & Pass \\
\hline 4 & user004 & 90 & Pass \\
\hline 5 & user005 & 92 & Pass \\
\hline 6 & user006 & 70 & Pass \\
\hline 7 & user007 & 90 & Pass \\
\hline 8 & user008 & 90 & Pass \\
\hline 9 & user009 & 87 & Pass \\
\hline 10 & user010 & 80 & Pass \\
\hline 11 & user011 & 90 & Pass \\
\hline 12 & user012 & 50 & No Pass \\
\hline 13 & user013 & 90 & Pass \\
\hline 14 & user014 & 90 & Pass \\
\hline 15 & user015 & 87 & Pass \\
\hline 16 & user016 & 90 & Pass \\
\hline 17 & user017 & 90 & Pass \\
\hline 18 & user018 & 90 & Pass \\
\hline 19 & user019 & 90 & Pass \\
\hline 20 & user020 & 90 & Pass \\
\hline 20 & user020 & 85 & Pass \\
\hline
\end{tabular}


Table 5. Topic 3 Testing Results on users

\begin{tabular}{|c|l|c|l|}
\hline No & User & Test Result & Status \\
\hline 1 & user001 & 70 & Pass \\
\hline 2 & user002 & 90 & Pass \\
\hline 3 & user003 & 88 & Pass \\
\hline 4 & user004 & 74 & Pass \\
\hline 5 & user005 & 92 & Pass \\
\hline 6 & user006 & 70 & Pass \\
\hline 7 & user007 & 90 & Pass \\
\hline 8 & user008 & 45 & No Pass \\
\hline 9 & user009 & 87 & Pass \\
\hline 10 & user010 & 80 & Pass \\
\hline 11 & user011 & 90 & Pass \\
\hline 12 & user012 & 85 & Pass \\
\hline 13 & user013 & 90 & Pass \\
\hline 14 & user014 & 90 & Pass \\
\hline 15 & user015 & 87 & Pass \\
\hline 16 & user016 & 45 & No Pass \\
\hline 17 & user017 & 86 & Pass \\
\hline 18 & user018 & 90 & Pass \\
\hline 19 & user019 & 85 & Pass \\
\hline 20 & user020 & 88 & Pass \\
\hline
\end{tabular}

The testing of this system was carried out in a small group consisting of 20 students of Informatics Engineering, State University of Malang. Tests on topics 1, 2 and 3 . Test results on topic 1 as shown in Table 3. In table 3,1 user cannot pass. The passing rate for topic 1 is $95 \%$. The test results on topic 2 as shown in Table 4 . In table 4 , 1 user cannot pass. The passing rate for topic 1 is $95 \%$. The test results on topic 3 as shown in Table 5. In table 5 there are 2 users who did not pass. The passing rate for topic 1 is $90 \%$. So, the average graduation in working on CTF questions is $93 \%$. While the average value for each topic is 81.75 for topic 1 , topic 2 is 86.2 and topic 3 is 81.1 . The graduation requirements for a topic are 75 . The average test score chart for each topic is shown in Figure 11. 


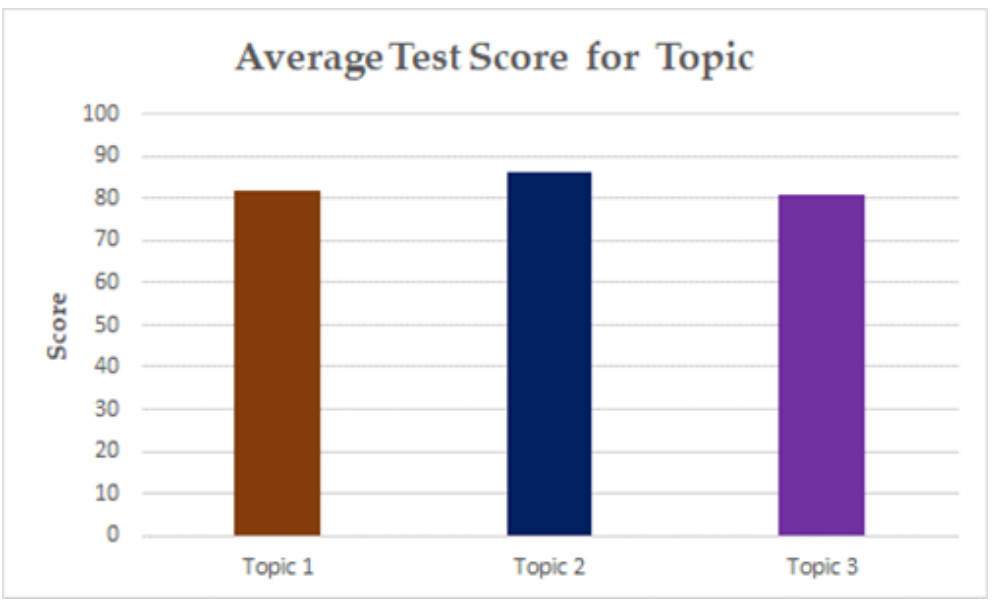

Fig. 11. Graph of average scores per topic with a total of 20 students of IT students

\section{Conclusion}

Based on the description of the results of the study, the following conclusions can be made an adaptive smart online course system based on a framework for solving CTF problems in the field of computer security networks. This system aims to improve the ability and expertise in the field of computer network security with a proven graduation rate and the average grade of students in completing CTF questions.

Testing the validation of adaptive smart online courses based on the adaptive framework using the Dick and Carey model and R\&D obtained an average passing rate of CTF questions of $93 \%$, and then based on this testing model, then the adaptive online course smart is declared valid.

\section{$5 \quad$ Acknowledgement}

IsDB funded this research for the 2019 budget in collaboration with PNBP Universitas Negeri Malang (UM) to support PUIPT DLI UM.

\section{$6 \quad$ References}

[1] Guo, T., Xu, C., He, S., Shi, B., Xu, C., \& Tao, D. (2019). Robust student network learning. IEEE transactions on neural networks and learning systems. https://doi.org/10.1109/tnnls.2019.2929114

[2] Randrianasolo, A. S., \& Pyeatt, L. D. (2014, December). Q-Learning: From Computer Network Security to Software Security. In 2014 13th International Conference on Machine Learning and Applications (pp. 257-262). IEEE https://doi.org/10.1109/icmla.2014.47

[3] Wirawan, I. M., Herwanto, H. W., \& Wahyono, I. D. (2017, October). Virtual programming laboratory UM (VLPUM) for programming competition. In Electrical, Electronics 
and In-formation Engineering (ICEEIE), 2017 5th International Conference on (pp. 158162). IEEE. https://doi.org/10.1109/iceeie.2017.8328781

[4] Ayodele, T., Shoniregun, C. A., \& Akmayeva, G. (2011, June). Towards e-learning security: A machine learning approach. In International Conference on Information Society (iSociety 2011) (pp. 490-492). IEEE https://doi.org/10.1109/i-society18435.2011.5978544

[5] Rashid, N. B. A., Othman, M., Johan, R., \& Sidek, S. F. B. H. (2019). Cisco Packet Tracer Simulation as Effective Pedagogy in Computer Networking Course. International Journal of Interactive Mobile Technologies, 13(10). https://doi.org/10.3991/ijim.v13i10.11283

[6] Capture the Flag (CTF). (2018). Tasks CTF. Taken: 17 January 2018, from https://ctftime.org/tasks

[7] Gong, X., Liu, H., \& Zhang, S. (2008, July). A collaboration-competition network model for teachers based on BA growing networks. In 2008 Chinese Control and Decision Conference (pp. 5134-5138). IEEE https://doi.org/10.1109/ccdc.2008.4598308

[8] Li, F. (2012, August). Study on security and prevention strategies of computer network. In 2012 International Conference on Computer Science and Information Processing (CSIP) (pp. 645-647). IEEE. https://doi.org/10.1109/csip.2012.6308936

[9] Wirawan, I. M., Taufani, A. R., Wahyono, I. D., \& Fadlika, I. (2017, October). Online judging system for programming contest using UM framework. In Information Technology, Computer, and Electrical Engineering (ICITACEE), 2017 4th International Conference on (pp. 230-234). IEEE. https://doi.org/10.1109/icitacee.2017.8257708

[10] Luo, S., \& Huang, X. (2012, April). A survey research on the online learning adaptation of the college students. In 2012 2nd International Conference on Consumer Electronics, Communications and Networks (CECNet) (pp. 107-110). IEEE https://doi.org/10.1109 /cecnet.2012.6202236

[11] Sun, X. (2011, December). The study on computer network security and precaution. In Proceedings of 2011 International Conference on Computer Science and Network Technology (Vol. 3, pp. 1695-1698). IEEE https://doi.org/10.1109/iccsnt.2011.6182293

[12] Rao, G. S., Kumar, P. N., Swetha, P., \& BhanuKiran, G. (2014, December). Security assessment of computer networks-an ethical hacker's perspective. In International Conference on Computing and Communication Technologies (pp. 1-5). IEEE. https://doi.org/10.1109/iccet2.2014.7066756

[13] Jolliffe, A., Ritter, J., \& Stevens, D. (2012). The online learning handbook: Developing and using web-based learning. Routledge https://doi.org/10.4324/9780203062432

[14] Li, Y., Gao, G., Chen, Z., \& Huang, R. (2009, May). Research on New Generation eLearning System for Ubiquitous Learning. In 2009 International Forum on Information Technology and Applications (Vol. 2, pp. 275-279). IEEE. https://doi.org/10.1109 /ifita.2009.374

[15] Rokhmawati, A., Kusumo, G. R., Wahyoho, I. D., \& Irawati, R. (2018, September). Ultranus: A Novel Indonesian Cultural Game Using Artificial Intelligence. In 2018 International Seminar on Application for Technology of Information and Communication (pp. 361-366). IEEE https://doi.org/10.1109/isemantic.2018.8549744

[16] Wahyono, I. D., Fadlika, I., Afandi, A. N., Faiz, M. R., \& Prihanto, D. (2018, September). Optimization Service Discovery in Wireless Balloon Network. In 2018 International Seminar on Application for Technology of Information and Communication (pp. 77-82). IEEE. https://doi.org/10.1109/isemantic.2018.8549828

[17] Divayana, D. G. H., Sappaile, B. I., Pujawan, I. G. N., Dibia, I. K., Artaningsih, L., Sundayana, I. M., \& Sugiharni, G. A. D. (2017). An evaluation of instructional process of expert system course program by using mobile technology-based cse-ucla model. Interna- 
tional Journal of Interactive Mobile Technologies (iJIM), 11(6), 18-31. https://doi.org/10.3991/ijim.v11i6.6697

[18] Wahyono, I. D., Taufani, A. R., Fadlika, I., Elmunsyah, H., \& Kusumo, G. R. (2018, September). Performance Discovery in Ubiquitous Networks. In 2018 International Seminar on Application for Technology of Information and Communication (pp. 338-344). IEEE. https://doi.org/10.1109/isemantic.2018.8549791

[19] Magal-Royo, T., Peris-Fajarnes, G., Montañana, I. T., \& Garcia, B. D. (2007). Evaluation methods on usability of m-learning environments. interactive mobile technologies, 1(1), 22.

[20] Wahyono, I. D., Fadlika, I., Taufani, A. R., \& Elmunsyah, H. (2018, October). Research in Ubiquitous Network: Communication Optimization using Publish-Subscribe. In 2018 Electrical Power, Electronics, Communications, Controls and Informatics Seminar (EECCIS) (pp. 202-206). IEEE. https://doi.org/10.1109/eeccis.2018.8692882

[21] Wahyono, I. D., Fadlika, I., Asfani, K., Putranto, H., \& Hammad, J. (2019, October). New Adaptive Intelligence Method for Personalized Adaptive Laboratories. In 2019 International Conference on Electrical, Electronics and Information Engineering (ICEEIE) (Vol. 6, pp. 196-200). IEEE. https://doi.org/10.1109/iceeie47180.2019.8981477

\section{Authors}

Irawan Dwi Wahyono is a lecturer in the Informatics Engineering Study Program at the Department of Electrical Engineering at Universitas Negeri Malang, Indonesia.. His research interests include: Intelligent Computing, Mobile Computing and Artificial Intelligence (email: irawan.dwi.ft@um.ac.id).

Djoko Saryono is a Full Professor at Universitas Negeri Malang with research in Cultural Studies, Poetry, Arts and Humanities (email: djoko.saryono.fs@um.ac.id).

Khoirudin Asfani is a lecturer in the Department of Electrical Engineering at Universitas Negeri Malang, Indonesia. His research interests include: Computer Networking, Web Programming, Learning and Education (email: khoirudin.asfani.ft@um.ac.id)

Muhammad Ashar is a lecturer in the Department of Electrical Engineering at Universitas Negeri Malang, Indonesia.. His research interests include: Intelligent Computing and Mobile Computing (email: muhammad.ashar.ft@um.ac.id)

Sunarti is a lecturer in Department of Letters, Universitas Negeri Malang. Her research interests include Literature, Linguistic and Culture (email: sunarti.fs@um.ac.id)

Article submitted 2020-04-15. Resubmitted 2020-05-21. Final acceptance 2020-05-22. Final version published as submitted by the authors. 